\title{
RAMAH LINGKUNGAN SEKOLAH DESA RENGASDENGKLOK SELATAN, KARAWANG, JAWA BARAT
}

\author{
Ferryal Abadi $^{1}$, Siti Nurjanah ${ }^{2}$ \\ ${ }^{1}$ Fakultas Ekonomi, Universitas Esa Unggul, Jakarta \\ Jalan Arjuna Utara No.9, Kebon Jeruk, Jakarta 11510 \\ ${ }^{2}$ Fakultas Bisnis, Institut Teknologi dan Bisnis Kalbis, Jakarta \\ Jl. Pulomas Selatan Kav 22, Jakarta 13210 \\ Email Korespondesi: ferryal@esaunggul.ac.id
}

\begin{abstract}
ABSTRAK
Desa Rengasdengklok Selatan merupakan salah satu desa bersejarah dalam proses kemerdekaan yang berlokasi di Kecamatan Rengasdengklok, Kabupaten Karawang, Jawa Barat. Desa ini dekat dekat Sungai CItarum. Sebagai salah satu Desa yang mempunyai objek wisata bersejarah kondisi masyarakatnya dalam menjaga kebersihan sangat rendah sehingga banyak sampah berserakan disekitar tempat wisata. Karena itu dalam rangka penyadaran kepada msyarakat kegiatan PKM ini ditujukan kepada siswa Sekolah Dasar sebagai penyadaran sejak dini akan kebersihan lingkungan dari lingkungan sekolah. Kegiatan ini dilakukan secara penyuluhan. Target luarannya yang dicapai kegiatan ini adalah pengetahuan siswa dan kesadaran siswa akan pentingnya kebersihan.
\end{abstract}

Kata Kunci : kebersihan, lingkungan, pendidikan

\begin{abstract}
South Rengasdengklok Village is one of the historic villages in the independence process located in Rengasdengklok District, Karawang Regency, West Java. The village is near near the Ctarum river. As one of the villages that has a historical tourist attraction, the condition of the community in maintaining cleanliness is very low so that a lot of garbage is scattered around the tourist spot. Therefore, in the context of raising awareness to the community, this PKM activity is aimed at elementary school students as an early awareness of the cleanliness of the environment from the school environment. This activity is carried out by extension. The output target achieved by this activity is student knowledge and student awareness of the importance of cleanliness.
\end{abstract}

Keywords: cleanliness, environment, education 


\section{PENDAHULUAN}

Lingkungan yang bersih ialah suatu keadaan dimana lingkungan terbebas dari kotoran seperti sampah, debu, dan juga bau tidak sedap. Menurut Indeks Perlindungan Lingkungan Tahun 2016, Indonesia menempati posisi ke-107 sebagai negara terbersih di dunia. Di Indonesia, masalah kebersihan lingkungan selalu menjadi perdebatan dan juga menjadi masalah yang terus berkembang.

Masalah lingkungan yang tidak bersih disebabkan karena kurangnya kesadaran masyarakat untuk menjaga kebersihan lingkungan. Tempat pembuangan sampah tidak dipergunakan dengan baik dan tidak terawat dengan baik pula sehingga mengakibatkan lingkungan menjadi kotor dan menimbulkan bau tidak sedap. Selain itu, lingkungan yang tidak bersih juga bisa menyebabkan berbagai macam penyakit seperti diare dan penyakit kulit.

Salah satu langkah yang dapat dilakukan untuk meningkatkan kesadaran akan pentingnya menjaga lingkungan yang bersih adalah dengan menanamkan rasa kepedulian dan cinta lingkungan sedari kecil atau masih kanak-kanak. Cara ini bisa dilakukan oleh para orang tua untuk mendidik anaknya sejak kecil agar ketika dewasa nanti anak tersebut sudah memiliki kesadaran untuk menjaga kebersihan lingkungan. Penanaman rasa kepedulian terhadap menjaga lingkungan yang bersih bisa dilakukan saat anak berada di rumah ataupun di sekolah.

Selain di rumah, banyak anak-anak yang menghabiskan waktunya di sekolah, seperti belajar dan bermain bersama teman-temannya. Oleh karena itu, guru juga memiliki peran yang penting dalam mendidik anak, terutama mendidik agar selalu memiliki kesadaran untuk menjaga lingkungan. Namun dalam mendidik murid-muridnya, seorang guru sering mengalami kesulitan seperti setiap anak memiliki watak yang berbeda-beda dan kesulitan dalam mengatur anak-anak karena masih dalam tahap pertumbuhan sehingga ketika guru mengajar para murid cenderung akan mengabaikannya.

Hal inilah yang menjadi hambatan bagi para guru dalam menanamkan rasa kepedulian menjaga kebersihan lingkungan kepada anak-anak. Hal itu tercermin pada murid-murid di SDN Rengasdengklok Selatan II, Karawang, Jawa Barat. Para murid cenderung kurang menyadari akan pentingnya menjaga kebersihan lingkungan. Para guru sudah kesulitan dan tidak memiliki cara lagi agar bisa menyadarkan para murid untuk menjaga lingkungan. Kondisi mitra secara umum merupakan sekolah negeri yang dimana lingkungan sekolahnya kurang bersih dan kurangnya tanaman sehingga menyebabkan lingkungan menjadi kurang indah untuk dipandang. Lingkungan kelas pun juga kurang bersih, seperti banyak sampah yang berserakan, lantai yang kotor dan tempat sampah yang kurang terawat.

Keterlibatan Perguruan Tinggi terutama dengan program Pengabdian Kepada Masyasrakat sangat dibutuhkan untuk mempercepat proses revitalisasi lingkungan. Sumbangsih keilmuan menjadi vital untuk merehabilitasi lingkungan alam yang rusak, membangunan kultur dan mentalitas masyarakat khususnya merevolusi gaya hidup bersih dan sehat, maupun untuk menangani dan memulihkan kondisi kesehatan masyarakat.

\section{METODE PELAKSANAAN}

Metode yang dilakukan adalah melalui penyuluhan mengenai pentingnya menjaga kebersihan lingkungan. Penyuluhan tersebut meliputi rangkaian materi sebagai berikut: (a) Motivasi tentang pentingnya menjaga lingkungan tetap bersih (b) Character Building 
tentang menaati perintah orang tua (c) Implementasi dalam menjaga lingkungan tetap bersih. Lokasi kegiatan SDN Rengasdengklok Selatan II, Jl. Perintis Kemerdekaan, Kecamatan Rengasdengklok, Kabupaten, Karawang, Jawa Barat

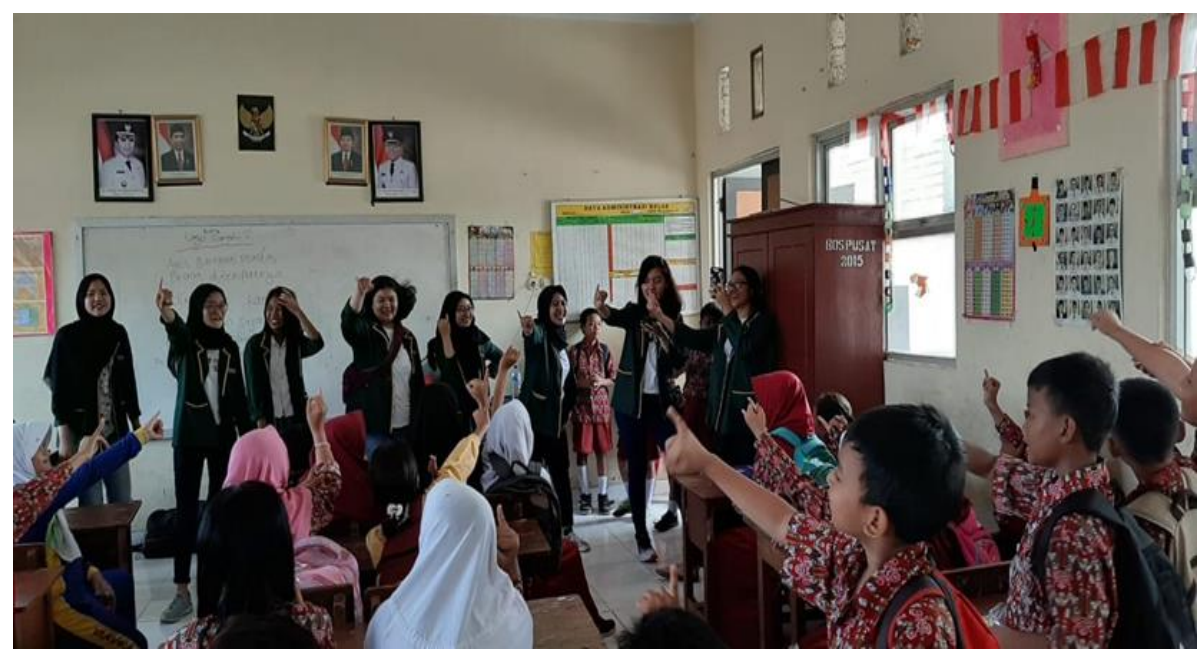

Gambar 1. Kegitan Sosialiasi

Pada penyuluhan yang dilakukan kepada siswa-siswi tidak hanya menggunakan metode presentasi tetapi juga memberikan games yang menarik agar siswa-siswi tidak merasa bosen dengan materi yang diberikan. Selain itu kita memberikan hadiah kepada siswa-siswa yang memenangkan games tersebut.Diskusi juga dilakukan dengan guru dan kepala sekolah agar kita dapat memberikan masukan-masukan agar sekolah dan lingkungannya selalu bersih

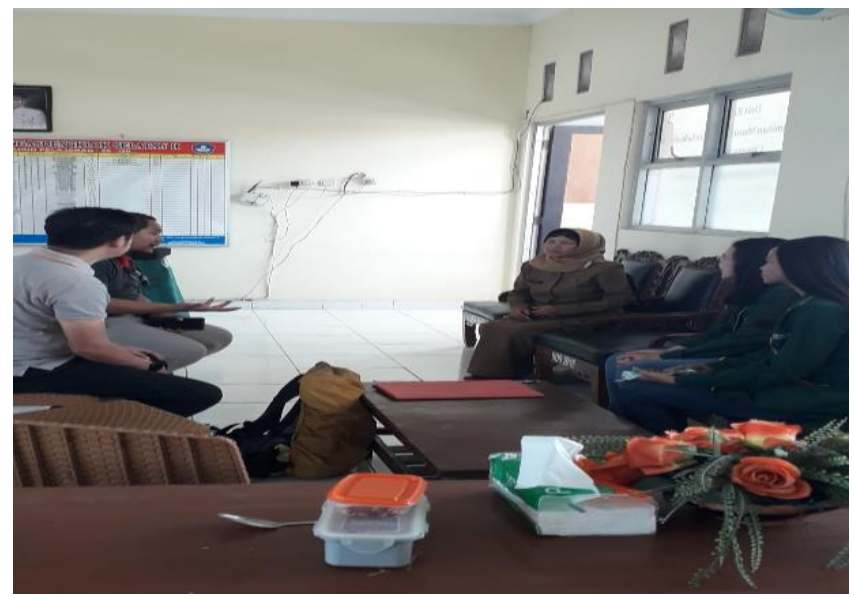

\section{Gambar 2 Diskusi dengan Kepala Sekolah}

\section{Evaluasi Kegiatan}

Setelah proses pelaksanaan diadakan evaluasi untuk melihat apakah penyuluhan yang diberikan memiliki indikator keberhasilan. Setelah proses pelaksanaan diadakan evaluasi untuk melihat apakah motivasi untuk menjaga kebersihan yang diberikan memiliki indikator kerberhasilan. 
Evaluasi yang dilakukan adalah dengan menerima feedback mitra PKM. Feedback tersebut adalah peserta penyuluhan merasa antusias dan senang selama penyuluhan berlangsung serta peserta penyuluhan juga akan lebih giat dalam melaksanakan piket kelas.

\section{Indikator Keberhasilan}

Ukuran indikator kerberhasilan suatu pelatihan bisa dilihat dari antusiasme mitra aktif dalam mengikuti pelatihan serta feedback dari mitra PKM. Ada dua indikator keberhasilan. (1) Motivasi murid SDN Rengasdengklok Selatan II meningkat; dan (2) Murid SDN Rengasdengklok Selatan II memulai menggiatkan kegiatan piket kelas

\section{Keberlanjutan Mitra}

Proses pelaksanaan PKM diharapkan dapat berlanjut lagi dengan terus memonitor kegiatan. Adapun keberlanjutan kegiatan di mitra dengan (1) Keberlanjutan proses pelaksanaan PKM yang diharapkan terus berlangsung adalah penyuluhan yang dapat menambah keahlian murid SDN Rengasdengklok Selatan II dalam menghias ruang kelas. (2) Keberlanjutan program ini akan dijalankan terus menerus sampai dengan tahun 2020.

Peran mitra dalam kegiatan PKM ini adalah sebagai peserta penyuluhan.Selain itu, khususnya kepada para guru akan memonitoring kebersihan kelas. Peran serta mitra lainnya dalam kegiatan berupa: (1) Sebagai penyedia lokasi, untuk diadakan penyuluhan (2) Sebagai peserta untuk penyuluhan kebersihan,

Tugas mitra dalam kegiatan PKM adalah mendengarkan sosialisasi yang dilakukan oleh narasumber dan mengimplementasikan materi penyuluhan yang telah disampaikan.

\section{KESIMPULAN}

Dengan kegiatan PKM ini manfaat yang diharapkan akan diperoleh diantaranya: (1).Para murid menjadi termotivasi untuk meningkatkan kesadaran pentingnya kebersihan di lingkungan mereka terutama di lingkungan sekolah, baik untuk kesehatan maupun keindahan lingkungannya.(2).Mahasiswa dapat meningkatkan kepedulian lebih baik lagi bagi kebersihan lingkungan sekitar mereka ataupun lingkungan di tempat lainnya.

\section{DAFTAR PUSTAKA}

Noelaka, A. (2008). Kesadaran Lingkungan. Jakarta: PT Rineka Cipta.

Suwardi, MS. (2001). Kearifan Lingkungan Masyarakat Melayu dalam Bunga Rampai Kearifan Lingkungan. Jakarta: Kementrian Lingkungan Hidup.

Dwiyatmo, K (2007), Pencemaran Lingkungan dan Penanganannya, Yogyakarta: Citra Aji Parama 